\title{
Michał Pietkiewicz
}

University of Warmia and Mazury in Olsztyn (Poland)

\section{The Military Doctrine of the Russian Federation}

\begin{abstract}
This paper investigates Russian Military Doctrines which establish the military construction and training of state armed forces and set out the forms and methods of conducting war. The main provisions of Military/Defense Doctrines have been formed and changed depending on current policy and the existent social system. This includes the level of productive forces and new scientific achievements and the nature of anticipated war. The 2014 Russian Military Doctrine defines the country as a strictly defensive entity and issues a list of provisions where Russia would be motivated to act militarily towards other countries. State policy and military doctrine are inextricably linked because the competent military policy meets all changes in international and domestic situations and successive military reforms are impossible without corresponding reflection in Military Doctrine.
\end{abstract}

Keywords: military doctrine; state security; territorial defense; Russian doctrine; Russian defense

This study highlights the Russian understanding of its particular interest and definitions of terms such as: "defense", "security" and "safety". It is currently imperative for all countries to define the defense of their sovereign territory in internal legal acts. Gen. Carl von Clausewitz and Gen. Antoiné Henri de Jomini developed general modern outlines of military/defense doctrines and Mikhail Vasilyevich Frunze formulated the specific basis for Soviet war doctrines and military reform. It is important to read military doctrines from a view point that guarantees state safety against domestic and external enemies while disregarding personal political belief and national interest. The study is therefore based on the views of military theorists from both ex-eastern and-western-block countries.

It is important to understand that the issue of transformation and changing the military doctrine of the state is a matter of transforming the model of its national security. The methods of reaction to external and internal threats described in the military doctrine reflect the strategic geopolitical goals of the state development and its determination to occupy a certain place in global security architecture. That is why it is indispensable to study and investigate the mechanism of changing the military doctrine depending on the 
changing reality and those conditions that contribute to the state in implementation of the plan for its own strategic development. What is meant here is, first and foremost, the political mechanisms and available resources, the mobilisation of which actually provides the opportunity to implement the military doctrine as such.

In terms of the research methodology, the greatest result within the framework of the issues under investigation can be achieved applying the methods of systemic and structural analysis, as well as the methods of retrospective and comparative legal analysis. The systematic nature of the study resides in the fact that the design of military doctrine as such presupposes the introduction of a network model of organising economic, political, military and other social relations in peacetime and wartime. Such a model covers all systemic spheres of state administration, forming by itself a system of national security.

As for structural analysis, it is more applicable to the very content of military doctrine and addresses the question of the expediency and effectiveness of such sequence of steps as secured by the doctrine. The retrospective analysis gives an understanding of the reasons for changing the military doctrine, the degree of its inclusiveness in the political sphere, as well as the level of its aggressiveness towards other states. The comparative-legal method makes it possible to compose risks and the degree of reaction of various states to them, thus defining the real strategic development goals. In addition, the analysis of the text of military doctrine and methods of its consolidation in the national legislation gives grounds to draw a conclusion as well as for the level of state guarantees of the principles of democracy.

\section{Military doctrines throughout the world}

The twentieth century concept of military doctrines has undergone significant changes. Military doctrine in the 1920's established construction of state armed forces and methods for training combat-troops and was driven by ruling state views on the nature and resolution of military problems. Dimitriev (2008) reported that Soviet military science developed a broader conceptual approach to war preparation and conduct in the late 1920's and 30's with associated plans to survive weapons of mass destruction (Dimitriev, 2008). This has supported the following military doctrine up to the present time: "the doctrine is formally adopted in the state and the armed forces with science-based views on the nature of war, methods of warfare and the consequences of these views on requirements for preparing the country and armed forces for war" (Donskoy, 2001).

Military doctrine now lost its purely military-strategic nature and includes ideological orientation and practical plans for politico-military and economic-military order (Dimitriev, 2008). Lider (1966) also recorded that $20^{\text {th }}$ century Russian military doctrine historical development has traversed several stages from the late 1920's/30's doctrine based on "deep operations" and the desire "to beat the enemy on its territory" (Aleshin, 2009).

The modern military doctrines of various states are quite often transformed from one program document into several strategic protocols and response algorithms of all spheres 
of social activity to possible and probable threats. The conceptualisation of threats is only a declaration of intention of the state in the event of their occurrence, and the readiness of a military confrontation.

For example, the modern military doctrine of Germany is represented outright by several documents: "White Paper on German Security Policy and the Prospects for the Development of the Armed Forces" (2006); "The Plan for Equipping the Bundeswehr with Weapons and Military Equipment" (2009); “The Main Directions of Germany's Defense Policy” (2011); “The Directive of the Inspector General for the Further Development of the Armed Forces" (2011). Whereby, from the point of view of the afore-referenced documents, "the greatest military danger for Germany is posed by: the potential crises in the European region, including in the post-Soviet space; international terrorism; the ongoing arms race; uncontrolled circulation of weapons and drugs, etc. (Dimitriev, 2014). At the same time, Berlin assigns the main role in confronting such threats to the consolidated combat tactical reaction groups of the EU and NATO and emphasises the creation of a strategic civil-military planning system.

The modern US military doctrine is based on the concept of full-spectrum operations, which simultaneously combine offensive, defensive and civil-military actions within the framework of interdependent joint forces for the capture, preservation and use of territories. US military doctrine presupposes a synchronised action - lethal and non-lethal - which is proportional to the mission and based on a detailed understanding of all aspects of the operating environment (Long, 2016). At the same time, the latest US military doctrine predetermines the state's being at war with global terrorism. Furthermore, the main risks for the US are also defined: religious (Islamic) fundamentalism; growth of drug trafficking; global militarisation; the threat of blocs that are aggressive towards the US strategic goals.

As Angstrom and Widén observe the UK military doctrine focuses on preserving the "danger of the emergence of "conventional" wars, including in the presence of nuclear weapons. At the same time, the likelihood of armed "clashes" and conflicts with the participation of non-state actors and "failed" states will increase significantly. Meanwhile, the main tasks of the British armed forces are: to protect the sovereignty and territorial integrity of the state; ensuring nuclear deterrence; participation in coalition operations overseas; assistance to civil authorities in the aftermath of catastrophes, etc." (Angstrom, Widén, 2015). It should be noted that a particular attention in the military doctrine is paid to information security due to the excessive penetration of information technologies into all spheres of public life in Great Britain. The state emphasises the need for protecting information of such sectors as: financial, energy, military-industrial, etc.

A new Russian military doctrine focused on integrated application of conventional and strategic weapons was created at the end of the 1950's and early 60's. This produced a combination of offensive and defensive armaments and forces and the concept of waging nuclear war (Donskoy, 2001).

These military doctrine provisions were introduced in the struggle for world domination between the two geopolitical ideologies of Soviet socialism and Western capitalism. The first 
was based on Marxist-Leninist theory of building socialism and proletarian internationalism (Sivkov, 2013) and the second proposed to contain the spread of socialist ideas. The latter intention aimed for the gradual degeneration of socialist countries and the establishment of Western world hegemony (Belozerov, 2013)

A main feature of the geopolitical confrontation was the use of military force by leading bloc countries. USSR and China became aligned against the US and UK and France. This period was characterised by many small wars in middle-Eastern and Indochina areas and some anti-Soviet uprisings in Eastern European countries (Best, 1997). The most striking episode was the Korean war with opposing armed forces led by the USSR and PRC against the United States and Britain and its allies. This phase ended in the 1950's when the USSR created nuclear weapons and an adequate delivery capability to deter direct military aggression (Sivkov, 2013).

The mutual aggression between the socialist and capitalist bloc was largely constrained from the early 1980's by the threat of the assured destruction of strategically important weapons of mass destruction. In 1982 the Soviet Union unilaterally pledged that it would not be the first to use nuclear weapons and these were then relegated to "a weapon of vengeance in a retaliatory nuclear strike" (Dmitriev, Polyanskiy, \& Trofimov , 2008).

\section{Military doctrines in the Russian Federation}

The sharp increase in conventional weapon destructive properties and the mutual understanding of ecological disaster, if these were used to destroy strategically important military and industrial facilities, highlighted that the State's desires to achieve political objectives by military means are absolutely unacceptable. Also, the desire threatens human existence which was officially expressed by the Socialist States bloc in the 1987"Declaration of States Parties to the Warsaw Pact'. This led to détente in international relations and strengthening of States' trust (Parzymies, 1999).

Russia developed its Military Doctrine following the collapse of the Soviet Union. This was secured in Berlin on May 29, 1987 with the signatures of the heads of the socialist countries as the "Military Doctrine of Warsaw Pact countries" (Abramov, 2007). This extended the existing Soviet Union military-political ideology.

\section{Military Doctrine}

Profound division in the Russian military environment followed USSR collapse. Part of the military remained loyal to the Soviet military doctrine based on quantity and power with minimal modernisation while others supported the radical reform of the entire armed forces (Wojnowski, 2015).

The first Russian military doctrine was formulated in November 2, 1993 presidential decree No. 1833 "On basic provisions of Military Doctrine of the Russian Federa- 
tion". These provisions developed the Russian Federation military doctrine which was approved in April 21, 2000 presidential decree No. 706 "On approval of the Military Doctrine of the Russian Federation". ${ }^{2}$ This was the first officially published military doctrine in the country's history and its structure comprised the following three main parts: (1) "Political Basis of the Military Doctrine; (2) Military Foundations of the Military Doctrine, and (3) Military-Technical Cooperation between the Russian Federation and Foreign Countries".

The "Basic provisions of Military Doctrine of the Russian Federation" approved by the Presidential decree from November 2, 1993 precised the following main domestic instances to be acted upon by Russian Federation forces:

- "illegal activity of nationalist, separatist and other organizations aimed at destabilising the Russian Federation internal situation and violation of its territorial integrity by use of armed violence",

- any "attempt to forcibly overthrow the constitutional order or disrupt functioning of organs of state power and control".

The Russian Federation 2000 Military Doctrine was as defensive as other post-Soviet era doctrines but the nature and threat in all areas of national security has changed (Babadjanov, 2008).

\section{Military Doctrine}

The exacerbation of traditional threats and the emergence of terrorism and armed separatism in the North Caucasus region were important reasons for adopting the new Military Doctrine of the Russian Federation approved in the presidential decree No. 706 from April 21,2000 . This doctrine characterised the global political and military situation and highlighted changes after the cold war. Section I clause 2 detailed the following military-political action against sabotage and terrorism: "reducing risk of large-scale war, including nuclear; the formation and strengthening of regional power centers; the strengthening of national, ethnic and religious extremism; the intensification of separatism; the spread of local wars and armed conflicts; the strengthening of regional arms races; proliferation of nuclear and other weapons of mass destruction and their means of delivery and exacerbation of informational confrontation" (Dmitriev, Polyanskiy, \& Trofimov, 2008). The federal authorities emphasised that terrorism and the level of threats to public safety and natural and technical disasters were the most important dangers for the Russian internal security (Menkiszak, 2014).

${ }^{1}$ Decree of the President of the Russian Federation of $2^{\text {nd }}$ November 1993 No. 1833 “On the Basic Provisions of the Military Doctrine of the Russian Federation”, http://base.garant.ru/6302237/\#ixzz4qoPHVjwN.

2 Decree of the President of the Russian Federation of 21 April 2000 No. 706 "On the Approval of the Military Doctrine of the Russian Federation”, http://base.garant.ru/181993/\#ixzz4qoOtOqe6. 
The 2000 Military Doctrine defined the strategic course and sequence of Russian leadership actions to ensure national security. Point 12 Part II noted "the Russian Federation firmly strives to create effective policies, legal, organisational, technical and other international guarantees for prevention of armed conflicts and wars" (Khohlov, 2005). The content stresses that aggressive changes to the existing status quo are not envisaged in the former Soviet Union or other global regions.

In the opinion of the authors of the doctrine, "in modern times, the threat of direct military aggression in traditional forms against the Russian Federation and its allies is reduced due to positive changes in the international situation, the holding by Russia of an active, peace-loving foreign policy, the maintenance at a sufficient level of Russian military capabilities, deterrence".

But, as we can see, in the eyes of the leading NATO countries, after the collapse of the Soviet Union, Russia did not pose a significant threat, moreover, it was treated as "to the Upper Volta with missiles."

\section{Military Doctrine}

After 10 years, thanks to high prices for raw materials, Russia's budget becomes surplus, the country begins to revive, its authority in the world grows, and accordingly the policy and the nature of the threats to its military security changes.

Content analysis confirmed previously declared Russian priorities in the security field in their validation that "the Military doctrine takes into account the main provisions of the Military doctrine of the Russian Strategy of development projects in the defense sector of the Russian 23 Federation, 2000, the concept of long-term socio-economic development of the Russian Federation for the period up to 2020 national security Strategy of the Russian Federation up to 2020, and relevant provisions of foreign policy Concept of the Russian Federation, 2008...." Clause "F" Section 21 postulates the requirement for “...expanding the circle of partner States and develop cooperation with them on the basis of common interests in strengthening international security in accordance with the provisions of the UN Charter and other norms of international law". This involved new cooperation formats including BRICS ${ }^{4}$ and $\mathrm{SCO}^{5}$ where states such as Brazil, India and China became Russian Federation partners (Kochetkov, 2015).

\footnotetext{
3 Decree of the President of the Russian Federation of 05.02.2010 No. 146 "On the Military Doctrine of the Russian Federation", http://www.kremlin.ru/ref_notes/461.

${ }^{4}$ BRICS - an association of five major emerging national economies: Brazil, Russia, India, China and South Africa.

5 SCO - The Shanghai Cooperation Organisation is a Eurasian political, economic, and security organisation, the creation of which was announced on 15 June 2001 in Shanghai, China by the leaders of China, Kazakhstan, Kyrgyzstan, Russia, Tajikistan, and Uzbekistan.
} 
This concept strived to build balanced security systems with the interaction of all key players. Particular attention focused on post-Soviet space and sought to enhance cooperation in international security in the Commonwealth of Independent States and increasing the capacity of collective security treaties. Thie concept proposed to organis security and cooperation in Europe and Shanghai and the development of relationships with interstate organisations such as NATO and the European Union (Burenok, Kosenko, \& Laavrinov, 2010).

The Military Doctrine of 2010 thus sought to introduce Russian national security interests in the changing international context and guarantee national interests while facing both old and new threats. The doctrine text also declares willingness to consider the interests of other powerful players if they are consistent with Russian Federation national interest. This approach indicated Russian desire to secure continued existence as an influential power center in global politics (Samarkina, 2014).

The 2010 doctrine made no significant changes to its defense policy. Russia has continued to perceive NATO and the US as potential opponents and co-operation with these powers was conditional on the willingness of US and the Alliance to include Russia's interests in war-political planning (Śmigielski, 2010).Thus, the Military Doctrine of 2010 seeks to inscribe the interests of Russia's national security in to the changing international context, to guarantee the national interests of the country in the face of old and new threats. At the same time, Russia's adherence to the norms of international law remained unchanged, its desire to ensure its security on equal terms, unlike the selective approach that the United States invariably demonstrates. In the Doctrine there is a readiness to take into account the interests of other influential players, if this does not contradict the national interests of the Russian Federation. From the declared approach, Russia's desire to ensure its continued existence as one of the most influential centers of power in world politics is evident.

\section{Military Doctrine}

The recent structure of threats to Russia's national interests changed significantly and counteraction was approved in the "Military Doctrine of the Russian Federation" by Presidential Decree No. Pr-2976 from December 25, 2014 (Colin C. , 2015). The 2014 Military Doctrine marked a qualitatively new stage in Russia's relations with the external world.

The Russian government associated eleven defined actions with potential issues or causes for military engagement. In essence they presented Russia as a defensive agent (Grätz, 2014) and Parchomenko confirmed that the 2014 doctrine outlined all actions viewed as particularly dangerous and capable of inciting Russian government response (Bodner, 2016).These actions included the "movement of NATO forces into global representation or bringing this infrastructure to Russia and attempting to destabilize regions of importance or strategic value to Russia or deployment of foreign military in countries or areas near Russia and its allies"(Norberg, 2014). The remaining conditions centered on: (1) deploying strategic 
anti-missile defense systems and undermining Russia's global stability or nuclear balance; (2) spreading the weapons of mass destruction; (3) using military force in the violation of the UN charter; and (4) spreading terrorism and any other instances of radicalised violence (Galeotti, 2016) (Sinovets i Renz, 2015).

The use of military force in the territories of states adjacent to the Russian Federation and its allies, in violation of the Charter of the United Nations (UN) and other norms of international law, is a fundamentally new threat. It is estimated that this may concern both the risks of a rapid US / NATO response to threats from the Islamic State in Central and Middle Asia, and to exaggerate the probability of NATO contingent entering Ukraine or other perimeter countries. In particular, it is possible that the Libyan scenario had an impact on Moscow's assessment of the actions bypassing the Russian veto in the UN Security Council.

The treatment of threats from global terrorism has been expanded. On the one hand, it is combined with the risks of extremism, and on the other hand, the risks of carrying out terrorist acts with the help of radioactive and toxic chemicals are outlined. For the first time, the Military Doctrine had mentioned the challenges posed by transnational organised crime in the sphere of illicit trafficking in arms and drugs. It is obvious that these threats are formed by the expectations of the development of the situation in Afghanistan and the region as a whole after the withdrawal of a contingent of American troops from it and the expectations of an escalation of the situation in the Caucasus.

The new military doctrine also established and defined current and relevant terms and conditions pertaining to the Russian Federation military. The events in Ukraine and deployment of confrontation with the US and EU demonstrated that Russia has faced the most serious challenges to national security since the early 1990's. However, at the enlarged session of the Collegium of the Ministry of defense in December 2014 President Vladimir Putin described the adoption of the 2024 Russian Federation Military document in the following manner "Our military doctrine does not change, it is purely defensive in nature, but we will defend our safety consistently and harshly" (Zhilin, 2014). The fundamental provision in the new document confirms that Russia will use military force to repel aggression against it and/or its allies and maintain/restore peace by decision of the UN Security Council and other collective security institutions. It further ensures the protection of its citizens outside the Russian Federation in accordance with universally recognised principles and international law norms backed up by Russian Federation international treaties. Radikov (2015) stresses that this is not conditional on the exhaustion of possibilities of applying non-violent measures (Radikov, 2015).

The Russian government has attempted to facilitate direct dialogue with European security agencies and most specifically with the EU and NATO (Hawk, 2016; Yashin i Shorina, 2015; McDermott, 2015). The provisions of the new doctrine outline an essentially defensive and security model meant to ensure that non-bloc principles are followed throughout the country. The doctrine further attempts to observe the conditions of international treaties and 
agreements with the Russian Federation for international limitations on nuclear weapons (Connell and Evans, 2015) and outlines Russia's capacity to readily arm itself and destabilise any issues directly pertaining to national security (Malenic, 2015).

Priority in cooperation in military-political and military-economic spheres is provided to CIS countries. The February 2010 Military Doctrine approves Russian consideration that NATO's extension to the East and the strengthening ties between the Alliance and post-Soviet States pose a distinct threat to Russian national interests. Russia currently applies open pressure and influence on regional countries by opposing closer ties and NATO Alliance membership for Ukraine, Moldova and Georgia. The doctrine's points are related to Russia’s preference for a stronger "Organisation of the collective security Treaty" and they emphatically confirm that Russian military-political priorities remain unchanged (Gates, 2009).

\section{Main provisions of the current Military Doctrine}

An analysis of the 2014 document and comparison with the 2010 manifesto provide evidence for the reassessment of the Kremlin's threats to national security and the exaggeration of military threats. The blending of offensive and defensive functions and revised approaches to equipping the Armed Forces are also designated.

There is also radically altered assessment of the current global situation (Baronin, 2014). The Alliance's power capacity and its infrastructural approach to Russian borders is presently the main external threat. It is important to emphasise that the 2010 military doctrine mentions NATO as an organisation that Russia could work with to "strengthen the system of collective security" but this was nullified in the new document. The 2014 doctrine text implies that the Alliance is the main geopolitical opponent because the current relations between Russia and NATO are wavering on the brink of armed confrontation and the text pointedly avoids mentioning the United States (Ivanov, 2014). Thus, we can see that in the text of military doctrine the enemy is clearly and logically designated. Obviously, the relationship between Russia and the West mentally returned to the situation of the Cold War. Both sides view each other as a probable adversary. From this, one or another measure for the deployment of their forces follows.

Many expected that in the text of the new military doctrine, which will become a completely new document, it will be clearly stated where the threats come from, what they represent, at what stage they can materialise, and who is their initiator. However, it did not happen, since the leadership of the Russian Federation has considered all the world centers of influence as hostile and as the sources of threats to national security.

This new Military Doctrine defines Russia's reaction to current events. For the first time Russia had stated its position on the legality of using force to repel aggression against it or its allies and this includes actions countering the decisions of the UN Security Council or other collective security structures and the protection of its citizens residing outside the country. Attacks or manifestations of aggression against the Union state and CSTO member 
states are deemed equally as an attack on Russia. This may indicate the prevalence of the defense concept in the Doctrine, based on the goal of retaining new gains of Russia in the Caucasus, Crimea and Ukraine. At the same time, this indicates the possibility of conducting the new stages of a hybrid war in the territory of the post-Soviet space within the framework of the protection of Russian-speaking population, after preliminary preparation in the form of granting citizenship. In this case, the southern and eastern parts of Ukraine, Moldova, Latvia and Kazakhstan appear in the risk zone (in decreasing order of probability).

In the military doctrine of the state owning nuclear weapons, there have been politically important guidelines on the principles and conditions of its application. The new doctrine allows Russia to continue developing and modernising nuclear capability and reserves the right to use nuclear weapons in case of provocation or threat from European powers (Winnerstig, 2014). This specifically coincides with Vladimir Putin's goal to reinstate elements of the Soviet Union. Attention is therefore drawn to the interesting point raised by Piontkovsky, the well-known Russian expert and senior researcher at the Institute for System Analysis (RAS). The author asserts that "the document proposed to write that Russia is prepared to use nuclear weapons in regional and even local conflicts" (Piontkovsky, 2016).

Moscow believes that military dangers for the Russian Federation have increased in some areas although the 2014 Military Doctrine indicated lower likelihood of large-scale war being unleashed against Russia because of its nuclear arsenal (Baronin, 2014). This is undoubtedly due to the 'information war' where both sides accuse each other of escalating conflicts (Darczewska, 2015). Europe still remains fully committed to protecting the United States' interests and Alliance troops have moved closer to Russian borders under the pretext of threats posed by the Russian Federation (Ivanov, 2013). The commentariat further suggested that the new Russian Military Doctrine contains no optimism for NATO-Russia relations despite being defined as "actively defensive" (Furgacz, 2015).

In this regard, the relevance of the military doctrine of the Russian Federation lies in the fact that it attempts to elaborate the new forms of warfare: informational warfare; hybrid war; international extremism. It is pointed out "the utilization of information and communication technologies for military and political purposes for carrying out actions that are contrary to international law directed against sovereignty, political independence, territorial integrity of states and posing a threat to international peace, security, global and regional stability poses a special danger for the Russian Federation. As also the establishment of regimes in the states adjacent to the Russian Federation, including those regimes established as a result of the overthrow of legitimate government bodies, whose policies are threatening the interests of the Russian Federation" ${ }^{6}$. The latter predetermines the possibility of conducting hybrid wars by seizing part of the territory of the Russian Federation by the way of taking advantage of

${ }^{6}$ Military Doctrine of the Russian Federation [Electronic resource] - Access mode: http://static. kremlin.ru/media/events/files/41d527556bec8deb3530.pdf 
the local population through the expression of its will in accordance with the international legal norms on plebiscite.

That being said, the problems of counteracting the information threat and the model of Russia's behaviour in the information war were spelled out very poorly in the Military Doctrine of the Russian Federation. This suggests that up until now, recognising the reality of the information threat, the Russian military-political decision-makers are trying to independently master the new kind of technological confrontation utilising the armed forces and military technologies.

\section{Conclusions}

It is obvious that military doctrines are not new. Almost every country has current strategic defense mechanisms collated in one document but perhaps not titled as "Military Doctrine". The major provisions in Russian military doctrines have changed significantly for the past 20 years but their core issues remain the same. This is despite the addition of new clauses which will align subsequent documents with Russia’s changing reality (Urbański, 2015). The Russian Military Doctrine determines "with whom we will jointly confront new threats" and specifies: (1) the CSTO; (2) BRICS countries; (3) Abkhazia; and (4) South Ossetia. It further stresses the necessity of maintaining equal dialogue with NATO and the European Union. The military doctrine aims are to be achieved by state and military management centralisation with the "implementation of complex political, diplomatic, economic, social, informational, legal, military and other measures aimed at ensuring the military security of the Russian Federation and its allies" (Kucheryavy, 2010).

Thus, it becomes obvious that the Military Doctrine, like any other doctrine, evolves. The situation changes, the state changes, the international security system changes, and the National Military Doctrine also changes. The analysis of the Military Doctrine of the Russian Federation from 2014 makes it clear that the document has a defensive character (Lubianoy, 2016). Many provisions of the doctrine did not change in comparison with the editors of 2010 , the provision on the use of nuclear weapons remained the same. In addition, in the doctrine of 2014, an item appeared, according to which Moscow pursues a policy of strategic deterrence, not only with nuclear weapons but also by conventional means, in particular by the use of precision weapons (2014). According to the published document, Russia is going to pursue a policy of equal dialogue with the EU and NATO, despite its current with them. Accents were also identified, for example, for the first time there had been an emphasis put on expanding cooperation with the BRICS member states, with the Shanghai Cooperation Organisation, and also for the first time there had appeared a provision on cooperation with the republics of Abkhazia and Ossetia in order to ensure joint defense and security (Kochetkov, 2015).

Particular attention was paid to the emerging position on the tasks in the Arctic region. It is about strengthening military security and ensuring economic functioning in the Arctic. 
From a military point of view, this is the region through which the trajectories of intercontinental ballistic missiles fly, the flights of strategic aviation of some countries, and also the area where submarines operate (Kozmenko, 2015).

It becomes obvious that the military-strategic documents of the Russian Federation meet all international and national dangers that Russia had faced. It can be assumed that the Russian Federation will have retaliatory measures against all threats of the outside world. Besides realising its foreign and domestic policy, Russia is achieving success in the military sphere, which causes concern for the outside world and strengthens confidence in the military power of Russian citizens.

On November 8, 2017, the All-Russian Center for the Study of Public Opinion published the results of a survey on the military threat to Russia. According to the results of the polls it became clear that more than a half of Russians does not believe that any country can attack Russia. This opinion was expressed by $53 \%$ of survey participants. At the same time, $47 \%$ of respondents considered the Russian army to be one of the best in the world, and 36\% put the RF Armed Forces in first place in the world. It is worth noting that in February 2015, $68 \%$ believed that there was a real threat of a military attack on Russia.

It is based on support and approval on the conviction of Russians that, in the event of a real military threat, the armed forces will effectively cope with the task of protecting citizens and the country, thanks, among other things, to the successful modernisation of armaments (Sitdikhov, 2017). The modernisation of weapons is considered the main achievement of the Armed Forces of the country over the past five years (this is indicated by $34 \%$ of the polled Russians).

The Russian vantage point demands that the state does everything in its power to provide national security for both its citizens and territory. The political value of the documents described in this article is ensured because their most important effects are targeted at deterring potential the State's enemies. There are many stipulations in the Russian Military Doctrines which may be considered incompatible with international law regulations, but possible justification exists in the meaning attributed to treaties and this is highly dependent on individual interpretation. But there is no secret to anyone that the Kremlin has laid the concept of a global military presence in the Military Doctrine, but the practical implementation of such a concept will be problematic.

\section{References}

Aleshin, V. (2009). "The evolution of threats to the military security of Russia (2000-2009)". Information jornal the army and society, 2, 14-20. elibrary.ru. Retrieved from: https://elibrary.ru/item. asp?id=12499774.

Abramov, M. (2007). "Naval doctrine as a component part of Russia's military doctrine". Bulletin of the Academy of military Sciences(1), 44-47. Retrieved from: https://elibrary.ru/item.asp?id=9473331. 
Affek, J. (2014). "Reformy i modernizacja Sił Zbrojnych Federacji Rosyjskiej”. Zeszyty Naukowe/Wyższa Szkoła Oficerska Wojsk Lądowych im. gen. T. Kościuszki, 1, p. 3.

Angstrom, J., Widén, J.J. (2014). Contemporary military theory: the dynamics of war. Routledge. p. 184. Babadjanov, A. (2008). "Analysis of the military doctrines of the states-participants of the CSTO". Vestnik MGIMO-University, 3, pages 60-66. Retrieved from: https://elibrary.ru/item.asp?id=11689965.

Baronin, A. (2017 December 29). “That means the new Military doctrine of the Russian Federation? (UNIAN news Agency)”. Unian.net. Retrieved from: https://www.unian.net/politics/1027585-chtooznachaet-novaya-voennaya-doktrina-rf.html.

Belozerov, V. (2013). “The military doctrine of the Russian Federation on the predictability of military conflicts". Electronic scientific journal of security problems, 3, pages 3-4. Elibrary.ru. Retrieved from: https://elibrary.ru/item.asp?id=21292042.

Berzins, J. (2014). "Russia's New Generation Warfare in Ukraine: Implications for Latvian Defence Policy". National Defence Academy of Latvia Center for Security and Strategic Research Policy Paper, 2, p. $1-13$.

Best, G. (1997). War and Law since 1945. Oxford: Clarendon Press.

Bitzinger, R. A. (2015). "Russian Arms Transfers and Asian Military Modernization”. www.rsis.edu.sg. Retrieved from: https://www.rsis.edu.sg/wp-content/uploads/2015/12/PR151215_Russian-Arms. pdf

Bodner, M. (2016). "NATO Deputy SecGen: Russia’s Anti-Access/Area-Denial BuildUp Is Biggest Worry”. DefenseNews. Retrieved from: https://www.defensenews.com/interviews/2016/02/14/nato-deputysecgen-russia-s-anti-access-area-denial-build-up-is-biggest-worry/

Burenok, V., Kosenko, A. and Laavrinov, G. (2010). „Technical equipment of the Armed Forces of the Russian”. Publishing house "Border", 3, page 728. Retrieved from: http://www.viek.ru/vie_10_3.pdf Chernova, O. (2012). "Conceptual bases of formation of system of ensuring national security and protecting national interests of the Russian Federation". Scientific works of the SWORLD, 17(2), pages 5-12. Retrieved from: https://elibrary.ru/item.asp?id=17828243

Colin, C. (2015). "The new military doctrine and humanitarian national security priorities Russia”. Strategic priorities international scientific-analytical journal(1), 30. Retrieved from: http://sec.chgik. ru/wp-content/uploads/2015/06/SP-15-5.pdf

Connell, M. E., and Evans, R. (2015). "Russia's "Ambiguous Warfare” and Implications for the U.S. Marine Corps”. CNA, Retrieved from: https://www.cna.org/CNA_files/PDF/DOP-2015-U-010447-Final.pdf Śmigielski, R. (2010). “Doktryna wojenna Federacji Rosyjskiej”. Biuletyn PISM, 28 (636), p. 2148.

Darczewska, J. (2015). Diabeł tkwi w szczegółach. Wojna informacyjna w świetle doktryny wojennej Rosji. Warszawa: Ośrodek Studiów Wschodnich im. Marka Karpia.

De Larrinaga, N. (2016). “Return of the bear”. IHS Jane’s Defence Weekly, p. 22-32.

Donskoy, U. (2001). "Greek military forces in Russia in the middle of the XVIII - first half XIX century”. Crimean Book. Retrieved from: http://crimeanbook.com/product/donskoy-ayu-grecheskie-voennyeformirovaniya-v-rossii-v-seredine-xviii--pervoy-polovine-xix-vv/

Dmitriev, Y. (2014). German Military Doctrine. Foreign Military Review, Vol. 12, p. 6-20.

Dmitriev, Y., Polyanskiy, I. and Trofimov, E. (2008). The military doctrine of the Russian Federation. Moscow: System GARANT.

Furgacz, P. (2015). „NATO po agresji Rosji przeciwko Ukrainie-kierunki reformy sojuszu i perspektywy na przyszłość". Ante Portas-Studia nad Bezpieczeństwem, 1 (4), p. 128.

Galeotti, M. (2016). “Russia's New National Security Strategy: Familiar Themes, Gaudy Rhetoric”. War on 
the Rocks. Retrieved from: http://warontherocks.com/2016/01/russias-new-134national-securitystrategy-familiar-themes-gaudy-rhetoric/

Grätz, J. (2014, April). “Russia’s Military Reform: Progress and Hurdles”. CSS Analyses in Security Policy, p. 152

Gates, R. (2009). „Balanced strategy”. Russia in global affairs. Retrieved from: http://www.globalaffairs. $\mathrm{ru} /$ number/n_12823

Hawk, J. (2016, January 30). “Russia Defense Report - Jan. 30, 2016: Fortress Kaliningrad”. South Front. Retrieved from: https://southfront.org/russia-defense-report-fortress-kaliningrad/

Ivanov, A. (2014, December 03). “To get to the English channel, or retreat to the Urals”. Free press. Retrieved from: http://svpressa.ru/politic/article/106024/

Ivanon, S. (2013). "Information warfare: the nature and main forms of". News of Altai state university. 4-2, pages $276-279$. Retrieved from: https://elibrary.ru/item.asp?id=21303125

Kalyuzhny, V. (2014, July 30). “National security as a factor of Russia's development”. Orienter, Retrieved from: http://orientir.milportal.ru/natsional-naya-bezopasnost-kak-faktor-razvitiya-rossii/

Karagiannis, E. (2014). “The Russian Interventions in South Ossetia and Crimea Compared: Military Performance, Legitimacy and Goals”. Taylor \& Francis Online. Retrieved from: http://www.tandfonline.com/doi/abs/10.1080/13523260.2014.963965/

Khohlov, I. (2005). “The military doctrine of the Russian Federation (21 April 2000)”. National Security. Retrieved from:: http://www.nationalsecurity.ru/library/00003/00003concept1.htm

Kochetkov, A. (2015). “The doctrines of the Russian state policy in the field of national security”. State and municipal management. Proceedings of the skags, pages 22-26. Retrieved from: https:/elibrary. ru/item.asp?id=24300541

Korolev, V. (2014, December 22). "Arctic military district headed by commander of the Northern fleet". Central Navy Portal. Retrieved from: http://flot.com/2014/179971/

Kozmenko, S. Bryzgalova, A. (2015). Prospects for the development of closed administrative-territorial entities in the Arctic, World (Modernization, Innovation, Development), 6/4-1 (24), pages 198-205

Kucheryavy, M. (2010). The military security of Russia. Ekaterinburg: Publishing house of the Ural University.

Lider, J. (1966). Wojny i doktryny wojenne XX wieku. Warszawa: Wiedza Powszechna.

Long, A. (2016). The Soul of Armies: Counterinsurgency Doctrine and Military Culture in the US and UK. Ithaca-London: Cornell University Press.

Lubianoy, V., Kryshkin, A. (2016). The strategy of national flawlessness and military doctrines of the US and Russia in the context of the development of a new geopolitical situation in the world: a comparative analysis. Actual problems of the humanities and social and economic sciences, 2, p. 138-141.

Malenic, M. (2015). “AFA 2015: Russia has closed air power gap with NATO, US warns”. Jane’s 360. Retrieved from: http://www.janes.com/article/54311/afa-2015-russia-has-closed-airpower-gapwith-nato-us-warns.

McDermott, R. N. (2015). “Brothers Disunited: Russia’s Use of Military Power in Ukraine”. Post-Soviet Armies Newsletter. Retrieved from: http://psan.hypotheses.org/1270

Menkiszak, M. (2014). Doktryna Putina: Tworzenie koncepcyjnych podstaw rosyjskiej dominacji na obszarze postradzieckim. Warszawa: Komentarze OSW.

Morris, T. S. (2015). “Securing Operational Access: Evolving the Air-Sea Battle Concept”. The National Interest. Retrieved from: http://nationalinterest.org/feature/securing-operational-access-evolvingthe-air-sea-battle-12219 
Neneth, W. (2015). “Russia's State-centric Hybrid Warfare”. Diplomaatia. Retrieved from: http://www. diplomaatia.ee/en/article/russias-state-centric-hybrid-warfare/

Norberg, J. (2014). "The use of Russia’s military in the Crimean crisis". Carnegie Endowment for International Peace, Retrieved from: http://carnegieendowment.org/2014/03/13/use-of-russia-s-militaryincrimean-crisis

Parzymies, S. (1999). Stosunki międzynarodowe w Europie 1945-1999. Warszawa: Wydawnictwo Akademickie Dialog.

Piontkovsky, A. (2016, March 26). “Nuclear poker. (Crimea.Reality)”. Retrieved from: https://ru.krymr. com/

Radikov, I. (2015). “The new nature of war in the xxi century and its reflection in the military doctrine of the Russian federation". Vestnik of Saint Petersburg university. Series 6. Political science. International relations, 2, pages 39-51. Retrieved from: https://elibrary.ru/item.asp?id=23764942

Romanovs, U. (2015). “The means and ends of Russia's security strategy in Riga Dialogue: Towards a Shared Security Environment. Afterthoughts from the Riga Security Seminar". In A. Sprūds (Eds.). Latvian Institute of International Affairs. Retrieved from: http://liia.lv/site/docs/RigaDialogues2015_web.pdf

RusNext.ru. (2016, Ju;y 30). „Russia will respond to reinforcement of NATO on its borders”. RusNext. ru Retrieved from:http://rusnext.ru/news/1467271532

Russel, M. (2015). "Russia's armed forces - Reforms and challenges". European Parliament. Retrieved from: http://www.europarl.europa.eu/RegData/etudes/IDAN/2015/554213/EPRS_ IDA\%282015\%29554213_EN.pdf

Samarkina, N. (2014). "Strategies and projects for the development of a modern defense sector of the Russian Federation.” Vestnik RGGU. Series: Political Science. History. International relations. Foreign area studies. Orientalism, 7, pages $21-28$. Retrieved from: https://elibrary.ru/item.asp?id=21769543

Sergeev, D. (2016, June 01). "Blow from the West than Russia will respond to reinforcement of NATO on its borders”. Zvezda. Retrieved from: https://tvzvezda.ru/news/forces/content/201606300748-jz1x. htm

Sinovets, P., i Renz, B. (2015). Russia's Syria operation reveals significant improvement in military capability. Rome: DeBooks Italia.

Sivkov, K. (2013, July 05). “Geopolitics of the USSR and Russia”. Military Review. Retrieved from: https:// topwar.ru/30424-geopolitika-sssr-i-rossii.html

Stepanov, A., Malezhik, M., Lubin , A. i Perepelitsyn, N. (2015). Medical care of the civilian population in time of war. Chita: Chita state medical Academy.

Sitdikhov, R. (2017). More than 90\% of Russians surveyed are confident in the army's ability to defend the country. Retrieved from: https://ria.ru/defense_safety/20171108/1508365069.html

Urbański, M. (2015). Doktryna wojenna federacji rosyjskiej z 2014 roku - dawny zwiąek radziecki w nowej odsłonie?. Przegląd Geopolityczny, 13, p. 20

Winnerstig, M. (2014). “Tools of Destabilization. Russian "Soft Power” and Non-military Influence in the Baltic States”. Centre for East European Policy Studies. Retrieved from: http://appc.lv/wp-content/ uploads/2014/12/FOI_Non_military.pdf

Wojnowski, M. (2015). “Koncepcja» wojny nowej generacji» w ujęciu strategów Sztabu Generalnego Sił Zbrojnych Federacji Rosyjskiej”. Przegląd Bezpieczeństwa Wewnętrznego, 7(13), p. 13.

Yashin, I., i Shorina, O. (2015). "Putin, War, An Independent Expert Report. Based on Materials from Boris Nemtsov”. Free Russia. Retrieved from: http://4freerussia.org/putin.war/Putin.War-Eng.pdf 
Zavrazhin, C. (2014). "Vladimir Putin: "Be strong: national security guarantees for Russia”'. Russian newspaper - Capital release(5708)

Zelenkov, M. (2013). Theoretical and methodological problems of the theory of national security of the Russian Federation. Moscow: Moscow state University of railway engineering (MIIT) Institute of Law.

Zhilin, A. (2014, December 20). Russia's right to preemptive strike: a military response to the economic war. Retrieved from: https://regnum.ru

\section{Author}

Dr Michał Pietkiewicz

University of Warmia and Mazury in Olsztyn, Faculty of Law and Administration, Department of Public International Law

Contact details: ul. Warszawska 98, 11-041 Olsztyn, Poland

e-mail: michal.pietkiewicz@uwm.edu.pl 